\title{
CONSERVATION MANAGEMENT AND LEGISLATION THE UK EXPERIENCE
}

\author{
SIBLEY P.J.
}

\begin{abstract}
Environment Agency, North Wessex Area, Rivers House, East Quay, Bridgwater, Somerset TA6 4YS, United Kingdom.

E-Mail: peter.sibley@environment-agency.gov.uk
\end{abstract}

Reçu le 8 septembre 2003

Accepté le 12 janvier 2004

Received September 8, 2003

Accepted January 12, 2004

\begin{abstract}
Underpinning the conservation management of Austropotamobius pallipes in the UK is the process of monitoring and reporting crayfish distribution. Should the current trend in the decline of $A$. pallipes continue, the species could be virtually extinct in mainland Britain within 30 years (SIBLEY, 2003). Conversely, if the increase in the distribution of non-indigenous crayfish species (NICS) continues at its current rate, the distribution (by $10 \mathrm{~km}$ squares) of these species could double within 15 years. These forward projections are based on a number of possibly unreliable assumptions; they illustrate however the magnitude of the challenge facing those concerned with the conservation of $A$. pallipes in the UK at this time.
\end{abstract}

Recent work in crayfish conservation management in the UK has yielded guidance in several areas including monitoring, habitat enhancement and a re-introduction protocol for $A$. pallipes (KEMP and HILEY, 2003). Similarly, scientific research continues to inform our understanding of the movement and behaviour of NICS and explores new methods for the potential management of these species. In addition, the protection afforded to A. pallipes by current legislation is key to the long-term survival prospects of the species, albeit with a probable fragmented distribution, across the British Isles and continental Europe.

Legal provisions in the UK derive in part from European instructions (e.g. EC Habitats and Species Directive) and also from national legislation (e.g. Salmon and Freshwater Fisheries Act (1975) and the Wildlife and Countryside Act (1981)). Also, a raft of "quasi-legislation" exists which requires responsible organisations in the UK to implement the white-clawed crayfish biodiversity action plan (BAP). Altogether these provisions constitute a considerable volume of legal protection for crayfish and provide the legal framework on which UK management policy and practice are based.

Key-words: conservation, crayfish, United Kingdom, legislation

\section{GESTION DE LA CONSERVATION ET LÉGISLATION - L'EXPÉRIENCE DU ROYAUME-UNI}

\section{RÉSUMÉ}

Le suivi et l'évaluation de la distribution géographique des écrevisses constituent la base de la stratégie de gestion des populations d'Austropotamobius pallipes au 
Royaume-Uni. Si le déclin observé des populations d'écrevisses autochtones se poursuit, Austropotamobius pallipes pourrait complètement disparaître de Grande Bretagne d'ici 30 ans (SIBLEY, 2003). Si, de leur côté, les écrevisses non-indigènes continuent leur expansion, leur distribution géographique pourrait doubler en 15 ans. Malgré l'incertitude entourant les suppositions soutenant ces projections dans le futur, elles illustrent bien l'importance du défi que doivent relever ceux en charge de la préservation de $A$. pallipes au Royaume-Uni.

Le travail déjà accompli en Grande Bretagne dans la gestion des ressources a permis d'établir des références dans les domaines du suivi des populations et de l'amélioration de I'habitat, ainsi qu'un protocole pour la réintroduction de Austropotamobius pallipes (KEMP and HILEY, 2003).

De plus, la recherche scientifique complète nos connaissances sur la migration et le comportement des écrevisses non-indigènes et permet d'envisager de nouvelles techniques pour la gestion de ces populations. La protection offerte à Austropotamobius pallipes par la législation actuelle joue un rôle décisif dans la survie de cette espèce en Europe et en Grande-Bretagne à long terme, sans empêcher sans doute la fragmentation de son aire de distribution.

La protection légale de Austropotamobius pallipes au Royaume-Uni est issue en partie des directives européennes et également de la législation nationale (Salmon and Freshwater Fisheries Act (1975) et Wildlife and Countryside Act (1981)). Un ensemble de "quasi-législation" existant nécessite des organisations responsables pour mettre en œuvre au Royaume-Uni le plan d'action pour la biodiversité des écrevisses à pattes blanches (BAP). La législation en place au Royaume-Uni offre aux écrevisses à pattes blanches une protection légale considérable et constitue la base sur laquelle se réalise la gestion des populations sur le terrain.

Mots-clés : préservation, écrevisses, Royaume-Uni, législation.

\section{DISTRIBUTION UPDATE}

Figure 1 illustrates the distribution of the indigenous crayfish species (ICS), A. pallipes, and NICS across mainland Britain by number of occupied 10-km squares of the Ordnance Survey National Grid. The solid lines show the plotted lines of best fit to date (using linear and polynomial regression calculations respectively for ICS and NICS) and the dotted lines show the forward projections estimated after 2003.

Should the current rate of decline in A. pallipes continue it is estimated that the species faces possible extinction in mainland Britain within approximately 30 years. Conversely, should the spread of NICS continue to increase, their distribution could double from 300 to $60010-\mathrm{km}$ squares within approximately 15 years.

These projections are based on the possibly unreliable assumption that current trends will continue unchecked. For further explanation of this point see SIBLEY (2003).

\section{LEGISLATION}

\section{Introduction}

Austropotamobius pallipes is still found in the wild in several European nations apart from the UK (namely Austria, Bosnia-Herzegovina, Croatia, France, Germany, Ireland, Italy, Liechtenstein, Portugal, Slovenia, Spain and Switzerland) (HOLDICH, 2002, 2003). In fact, in some of these countries (but not including the UK) there are now known to be two clearly separated species, A. pallipes and Austropotamobius italicus (GRANDJEAN 


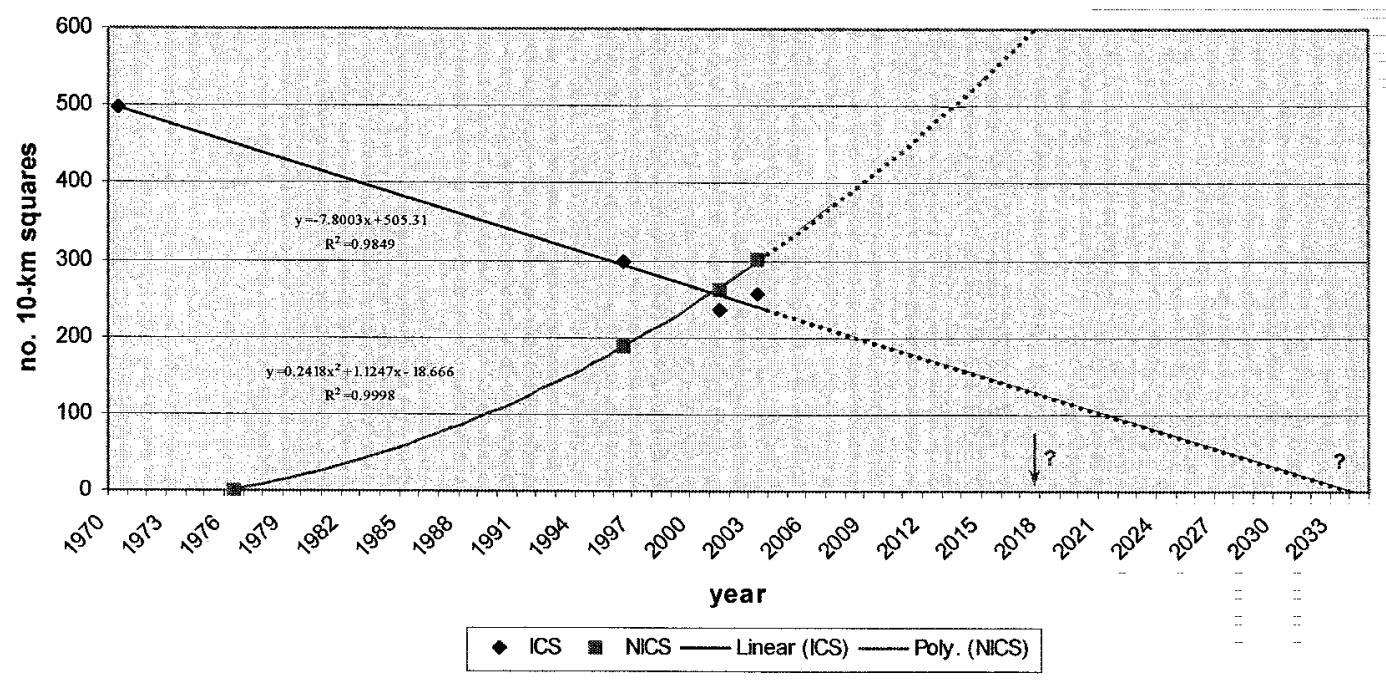

Figure 1

Number of $10-\mathrm{km}$ squares of the Ordnance Survey National Grid occupied by crayfish in mainland Britain.

Figure 1

Nombre de carrés de $10 \mathrm{~km}$ de côté de l'“ Ordnance Survey National Grid " où l'écrevisse est présente en Grande-Bretagne.

et al., 2002), a development which, if anything, necessitates more stringent or specific conservation management in order to protect both genetic entities.

The main legislation covering the conservation and management of crayfish in the UK is outlined below. These provisions include elements of over-arching European legislation, which apply to all signatory nations with resident crayfish populations. Further to this, the UK has enacted a range of formal and informal provisions designed to conserve A. pallipes, and it is worth considering the level of protection these afford in comparison with provisions from other countries.

\section{European Legislation}

Two key pieces of European legislation, designed largely to protect exploited species, have resulted in improved protection for $A$. pallipes in the UK, despite the fact that the species has certainly not been commercially harvested in the wild here, for many years. (Similarly, there is no longer any significant exploitation of $A$. pallipes in mainland Europe.)

The main objective of the Bern Convention 1979 is to conserve wild fauna and flora, with the emphasis on endangered and vulnerable species. A. pallipes is listed on Appendix III of the Convention (along with Astacus astacus and Austropotamobius torrentium), requiring signatories to regulate exploitation. This is not an issue in the UK, nor currently in most of the European countries listed in the introduction above. The Bern Convention has not banned the introduction of any NICS.

The EC Habitats and Species Directive 1992 (Habitats Directive) in part provides a mechanism for the protection of species listed under the Bern Convention. This Directive has been signed and adopted by all countries containing the $A$. pallipes complex. The species is listed on Appendix II of the Directive, requiring member states to designate Special Areas of Conservation (SACs) for the protection of the species. Along with 
A. astacus and $A$. torrentium it also appears on Appendix $\mathrm{V}$, which requires that taking the species from the wild, whether for exploitation or otherwise, does not jeopardise its maintenance at a favourable conservation status. The way in which the UK applies this legislation is outlined below along with other relevant provisions.

\section{UK Legislation}

\section{Conservation (Natural Habitats, \& c.) Regulations 1994}

The Conservation (Natural Habitats, \& c.) Regulations 1994 effectively implement the Habitats Directive by facilitating the establishment of SACs in the UK. Selection criteria for $A$. pallipes dictate that candidate SACs should be relatively isolated; that the keeping of NICS should not be permitted in the area; that the habitat should be of high quality; and that the crayfish population should comprise healthy, breeding stock. To date 10 candidate SACs have been proposed in the UK on the basis of their crayfish populations (although at two of these this was not the primary reason for notification) (JNCC WEBSITE). Other European countries have also designated candidate SACs on the basis of $A$. pallipes (e.g. there are 14 proposed SACs in Ireland (VIGNEUX et al., 2002)).

\section{Wildlife and Countryside Act 1981}

Another major piece of nature conservation legislation in the UK is the Wildlife and Countryside Act 1981 (WCA). A. pallipes was added to Schedule 5 of the WCA following its listing on appendix $V$ of the Habitats Directive, effectively protecting it from taking (including handling) or sale in England, Wales and Scotland. It was proposed to add the species to the Wildlife (N. Ireland) Order 1985, but this has not yet taken place. Licences are required from the country conservation agencies (e.g. English Nature) to carry out surveys for $A$. pallipes or otherwise move specimens. Consent is also required to undertake a number of listed potentially damaging activities in designated areas such as Sites of Special Scientific Interest (SSSI). In 2001 the creation of the Countryside and Rights of Way Act served to strengthen the provisions of the WCA. At the time of writing the maximum penalties under this legislation are a fine of $£ 5000$ and two years imprisonment. There is no record of any crayfish related prosecution being made by the police under the WCA.

Under Section 14 of the WCA it is an offence to release into the wild animals that are either "not ordinarily resident" or have been listed as pest species on Schedule 9 of the Act. Three NICS are currently listed on Schedule 9, namely Pacifastacus leniusculus, Astacus leptodactylus and Astacus astacus. There are currently two other NICS, Orconectes limosus and Procambarus clarkii, present in the UK, which have not yet been listed on Schedule 9. Since these are breeding in the wild, both could theoretically be described as "ordinarily resident". It would be preferable to close this loophole and list these two species, a process made possible under a system of five yearly reviews. In Northern Ireland it is an offence under the Wildlife ( $N$. Ireland) Order to release animals not normally resident. There are no known populations of NICS in the wild anywhere in Ireland (HOLDICH, 2003; OLDAKER, 2003) and it is clearly important for the future survival of $A$. pallipes that the island is protected from colonisation by these species. One need only look across the Irish Sea at mainland Britain to see how rapidly an island population of native crayfish has declined in less than 30 years since the first NICS were introduced to Southern England.

Broadly parallel legislation exists elsewhere in Europe, for example the Federal Nature Conservation and Protection Act (NCPA) and Federal Species Protection Ordinance in Germany (VON LUKOWICZ, 1999). It is interesting to note that, as with the WCA, problems arise with the definition of what is an "indigenous" or "native" species. Under the NCPA, there is no legal difference between the three endemic German species $(A$. 
astacus, $A$. torrentium and $A$. pallipes) and those introduced but self-maintaining species (e.g. O. limosus and $P$. leniusculus). The latter are therefore regarded as legally native.

\section{Prohibition of Keeping of Live Fish (Crayfish) Order 1996}

The UK government introduced the Prohibition of Keeping of Live Fish (Crayfish) Order in 1996. This "Crayfish Order" made it an offence to keep NICS anywhere in England and Wales without a licence, with a few exceptions (SCOTT, 2000). The main exception was that $P$. leniusculus might be kept without a licence in designated areas, mainly in the south of England where it was already widespread. Conversely, much of the midlands and north of England and Wales were designated as "no-go" areas in which the unlicensed keeping of $P$. leniusculus is not permitted. Other exceptions were made for the few existing crayfish farms, for keeping for direct human consumption and for the keeping of a single tropical species, Cherax quadricarinatus, in heated indoor aquaria. The maximum fine that can be imposed under this legislation is $£ 2500$. Parallel legislation has been introduced in Scotland and, as mentioned above, the introduction of NICS to Northern Ireland is illegal.

\section{Salmon and Freshwater Fisheries Act 1975}

Most European countries have specific fisheries authorities and laws, often designed to produce and conserve a healthy stock of fish for the purpose of exploitation. Some countries, such as Austria, France and Italy, consider crayfish to be fish in law (VIGNEUX et al., 2002). Due to its status as a fish in Austria, there is a legal requirement for certain waters to be re-stocked with indigenous crayfish when numbers have declined or been eliminated by disease (PÖCKL, 1999). In practice however, this seldom occurs.

In the UK, under the Salmon and Freshwater Fisheries Act 1975 crayfish are also legally classified as fish (Caygill $v$ Thwaite (1885) and government response to the Salmon and Freshwater Fisheries Review). This legislation regulates many aspects of fishing and fisheries management and allows for the creation of regional and national fisheries byelaws. Under the 1975 Act it is illegal to place traps (fixed engines) for crayfish in freshwaters, whether for conservation purposes or commercial gain. However, the trapping of $P$. leniusculus is made legal under a regional byelaw in the Thames catchment of England. The Environment Agency, Thames Region recently prosecuted an individual for using unlicensed instruments to take crayfish, resulting in a fine of $£ 1000$ (GREENWOOD, 2002). At the time of writing a national byelaw for England and Wales is being proposed which would regulate trapping for crayfish in all parts of England and Wales. This proposes that in the "no-go" areas stipulated in the "Crayfish Order" trapping would only be authorised for fisheries management, conservation and scientific research purposes. Elsewhere, trapping could also be authorised for commercial purposes and the operator would be required to provide catch data and adhere to certain trap specifications and conditions.

In other European countries (e.g. Belgium and Luxembourg) the capture of A. pallipes is strongly restricted or forbidden, whereas NICS may be taken. In France and Switzerland however, national regulations permit the capture of indigenous crayfish during open seasons. The introduction or transport of live O. limosus and P. leniusculus (species considered as causing biological disturbances in nature) is forbidden in France. (Special regulation decrees that, should $P$. clarkii be captured, it must immediately be killed.) (ARRIGNON et al., 1999; VIGNEUX et al., 2002)

Under additional fisheries legislation in the UK a national byelaw has been introduced which makes it an offence to use any species of crayfish, alive, dead, or part thereof as bait. This byelaw aims to reduce the risk of spreading disease or indeed live NICS.

Fish introductions, including crayfish, are also regulated under the 1975 Act. With respect to crayfish this effectively applies to $A$. pallipes only, since it is an offence under 
the Crayfish Order to release NICS. Any proposal to introduce or relocate A. pallipes would therefore require (Section 30) consent from the Environment Agency. This is in addition to the licensing requirements imposed by the country conservation agencies under the WCA. All aspects of crayfish translocation are covered by the LIFE in UK Rivers re-introduction protocol (KEMP and HILEY, 2003), a draft of which is available on the English Nature WEBSITE.

\section{Environment Agency policy}

As the leading public body for protecting and improving the environment in England and Wales, the Environment Agency plays a fundamental role in crayfish conservation and fisheries management.

The removal of fish (including crayfish) from inland waters (e.g. by hand or net for survey purposes) requires consent from the Environment Agency. This is separate from the consenting process required for commercial trapping. (The necessary form, FR2, and guidance notes are available to download from the EFISHBUSINESS WEBSITE.)

Work instructions advise Agency staff involved with the regulation of fish movements and stipulate that the source of any fish intended for stocking into catchments with A. pallipes designated SSSIs or candidate SACs must be investigated. Restrictions are placed on fish being moved from waters with a history of crayfish plague or NICS present. For other receiving waters, a series of measures are specified as a precaution against the accidental transfer of disease or crayfish (e.g. disinfecting of equipment and use of "neutral" water in which to transfer fish). In addition to the re-introduction protocol, the Environment Agency and English Nature have jointly published guidance on works affecting native crayfish (PEAY, 2000), habitat improvements (PEAY, 2003) and a monitoring protocol (PEAY, 2002), all of which contain valuable information for staff and external users.

\section{"Quasi-Legislation"}

As well as the main statutory provisions outlined above, the UK government, in common with other European nations, has certain obligations to protect biological diversity. In the UK these obligations have led to the development of informal or "quasilegislation".

\section{Biodiversity Action Plans}

The UK is a signatory to the Convention on Biological Diversity, held in Rio de Janeiro in 1992, and as a result published its own UK Biodiversity Action Plan in 1994 (HMSO, 1995). A. pallipes was identified as a priority species for which a species action plan was subsequently published with the aim of preventing any further decline in population. Various bodies such as the Environment Agency and English Nature have responsibilities to implement the action plan, and key actions have been cascaded into the published plans of local government, regional conservation organisations and other groups involved with practical conservation management.

Elsewhere in Europe, many of the Scandinavian and Baltic countries have long practised the management of crayfish for conservation and exploitation (SKURDAL et al., 1999). Protection, restoration, enhancement of indigenous species and sustainable exploitation have all figured as key objectives in recent crayfish action plans, sharing common ground with work in the UK and other countries.

\section{Review of non-native species policy}

In 2003 the Department for Environment, Food and Rural Affairs (DEFRA) published a Review of non-native species policy (DEFRA, 2003). This working group report considered 
the introduction, establishment and spread of non-indigenous species, including crayfish, and made a number of key recommendations to limit ecological and economic impact. These recommendations share key themes with the objectives of CRAYNET (REYNOLDS and SOUTY-GROSSET, 2003) and are summarised briefly as follows:

- improvements to co-ordination of action required,

- improved risk assessment systems to help prioritise action,

- new preventative measures such as public awareness campaigns,

- revisions to legislation,

- improvements to monitoring,

- policies on management of invasive species,

- engagement with stakeholders.

DEFRA is currently considering the report and will develop a government strategy in response.

\section{CONCLUSION}

Despite the raft of measures described above, the decline in distribution of A. pallipes and expansion of non-indigenous crayfish species has continued in mainland Britain. However, existing UK legislation clearly has direct and indirect benefits for our single indigenous crayfish species and for its habitat. New legislation continues to plug the gaps whilst evolving guidance highlights best practice for those involved in conservation management.

The survival of $A$. pallipes in the UK, and elsewhere in Europe, may well depend on how successfully remote populations are protected (be they isolated headwaters, designated SACs or even entire islands such as Ireland or Corsica). It is clearly important that the network of designated SACs receives full protection under the national legislation of individual countries. European legislation needs also to catch up with recent advances in the genetic differentiation of $A$. pallipes from $A$. italicus in order that the latter receives the formal level of protection afforded to $A$. pallipes under the Bern Convention etc.

Relevant legislation, supported by adequate enforcement, has a crucial role to play in crayfish conservation management and the UK experience provides a potentially useful example for other countries seeking to further develop their own legal provisions. Time will tell whether or not the efforts to combat the spread of NICS and conserve indigenous European crayfish are successful. Meanwhile, every reasonable step should be taken to ensure that $A$. pallipes, a flagship species of cultural and scientific importance, receives the best possible protection under UK and European law.

\section{ACKNOWLEDGEMENTS}

Thanks are due to Julian Reynolds, David Holdich and Paul Lidgett for their help and advice, and to Jo Oldaker for her review of existing UK legislation.

\section{REFERENCES}

ARRIGNON J.C.V., GÉRARD P., KRIER A. and LAURENT P.J., 1999. The situation in Belgium, France and Luxembourg. In: Crayfish in Europe as alien species - how to make the best of a bad situation? (GHERARDI F. and HOLDICH D.M., Eds.), 129-140. Crustacean Issues 11. Balkema, Rotterdam. 
Department for Environment, Food and Rural Affairs (DEFRA), 2003. Review of non-native species policy. Report of the working group. DEFRA Publications, London.

EFISHBUSINESS WEBSITE. http://www.efishbusiness.com

ENGLISH NATURE WEBSITE. http://www.english-nature.org.uk/LIFEinUKRivers/ publications/ publications.html

GRANDJEAN F., FRELON-RAIMOND M. and SOUTY-GROSSET C., 2002. Compilation of molecular data for the phylogeny of the genus Austropotamobius: one species or several? In: Knowledge-based management of European native crayfish. Crayfish special Vol. 4 (SOUTY-GROSSET C. and GRANDJEAN F., Eds.). Bull. Fr. Pêche Piscic., 367, 671-680.

GREENWOOD V., 2002. Crayfish dealer fined $£ 900$ for illegally using traps. Biodiversity News, 20 , p. 6.

HMSO., 1995. Biodiversity: The UK Steering Group Report - Volume II: Action Plans., Tranche 1, p. 157, HMSO.

HOLDICH D.M., 2002. Present distribution of crayfish in Europe and some adjoining countries. In: Knowledge-based management of European native crayfish. Crayfish special Vol. 4 (SOUTY-GROSSET C. and GRANDJEAN F., Eds.). Bull. Fr. Pêche Piscic., 367, 611-650.

HOLDICH D.M., 2003. Crayfish in Europe - an overview of taxonomy, legislation, distribution, and crayfish plague outbreaks. In: Management and Conservation of Crayfish. Proceedings of a conference held on $7^{\text {th }}$ November, 2002 (HOLDICH D.M. and SIBLEY P.J., Eds.), 15-34. Environment Agency, Bristol.

JNCC WEBSITE. http://www.jncc.gov.uk/ProtectedSites/SACselection/SAC_List_features .asp?Unitary=\&Feature=S1092.

KEMP E.J. and HILEY P.D., 2003. A protocol for reintroducing white-clawed crayfish. (Short communication). In: Management and Conservation of Crayfish. Proceedings of a conference held on $7^{\text {th }}$ November, 2002 (HOLDICH D.M. and SIBLEY P.J., Eds.), 143-145. Environment Agency, Bristol.

OLDAKER J., 2003. A brief overview of the legislation covering indigenous and nonindigenous crayfish in the UK. In: Management \& Conservation of Crayfish. Proceedings of a conference held on $7^{\text {th }}$ November, 2002 (HOLDICH D.M. and SIBLEY P.J., Eds.), 87-93. Environment Agency, Bristol.

PEAY S., 2000. Guidance on Works Affecting White-clawed Crayfish., 27 p. English Nature, Peterborough.

PEAY S., 2002. A Standardised Monitoring Protocol for White-clawed Crayfish, Austropotamobius pallipes, in the UK SAC Rivers. Life in UK Rivers Project. Contract LIFE 02-11-37., 58 p. English Nature, Peterborough.

PEAY S., 2003. Guidance on habitat for white-clawed crayfish and how to restore it. R\&D Technical Report W1-067/TR., 66 p. Environment Agency, Bristol.

PÖCKL M., 1999. Freshwater crayfish in the Legislation of Austria: Federal, National and International Laws. Freshwater Crayfish, 12, 899-914.

REYNOLDS J.D. and SOUTY-GROSSET C., 2003. CRAYNET: Programme and potential. In: Management and Conservation of Crayfish. Proceedings of a conference held on $7^{\text {th }}$ November, 2002 (HOLDICH D.M. and SIBLEY P.J., Eds.), 2-14. Environment Agency, Bristol. 
SCOTT A., 2000. Crayfish conservation, legislating for non-native species. In: Crayfish Conference Leeds (ROGERS D. and BRICKLAND J., Eds.), 27-31. Environment Agency, Leeds.

SIBLEY P.J., 2003. The distribution of crayfish in Britain. In: Management and Conservation of Crayfish. Proceedings of a conference held on $7^{\text {th }}$ November, 2002 (HOLDICH D.M. and SIBLEY P.J., Eds.), 64-72. Environment Agency, Bristol.

SKURDAL J., TAUGBØL T., BURBA A., EDSMANN L., SÖDERBÄCK B., STYRRISHAVE B., TUUSTI J. AND WESTMAN K., 1999. Crayfish introductions in the Nordic and Baltic countries. In: Crayfish in Europe as alien species - how to make the best of a bad situation? (GHERARDI F. and HOLDICH D.M., Eds.), 193-219. Crustacean Issues 11. Balkema, Rotterdam.

VIGNEUX E., THIBAULT M., MARNELL F. AND SOUTY-GROSSET C., 2002. National legislation, EU directives and conservation. In: Knowledge-based management of European native crayfish. Crayfish special Vol. 4 (SOUTY-GROSSET C. and GRANDJEAN F., Eds.). Bull. Fr. Pêche Piscic., 367, 887-898.

VON LUKOWICZ M., 1999. Freshwater crayfish in the fishery legislation of the federal states (Bundesländer) of Germany (O). Freshwater Crayfish, 12, 890-898. 